\title{
História, analogia e natureza em Novalis
}

\author{
[The history, analogy, and nature of Novalis] \\ http://dx.doi.org/10.11606/1982-88372341125
}

\section{Eduardo Guerreiro Brito Losso ${ }^{1}$}

\begin{abstract}
By determining the three stages of the historical fate of the West in Christendom or Europa, Novalis promises a future synthesis between the Middle Ages and the Enlightenment from the point of view of the German romantic savant. In this future, the scientific and philosophical enthusiasm converge with mystic and poetic rapture instead of countering it. It reconciles art and science, sensitivity and spirituality, nature and history, sacred and profane. However, in the novel The Novices of Sais there is a series of vertiginous correlations between nature, spirit, body and history that could not have been made by a scientist. They could have only been fashioned by a poet, the only one who comprehends the meaning of nature. This article describes how the concept of re-enchantment in both books is connected to the analogous renaissance understanding which, according to Hartmut Böhme, introduces a semiology of nature based on the connecting similarities of things. If, during the Renaissance, it is the natural philosopher who deciphers the meaning of things, in Novalis's work it is the poet who uses language as the key to re-enchanting and freedom. This paper concludes by reflecting upon the conflict of illusion and reality in modern poetry.
\end{abstract}

Keywords: Novalis; Modern Poetry; Nature; Analogy; Re-enchantment.

Resumo: Ao formular as três etapas do destino histórico do Ocidente em Cristandade ou Europa, Novalis oferece a promessa de uma síntese futura entre a Idade Média e o Iluminismo na figura do erudito alemão romântico. Nele, o entusiasmo científico e filosófico irá ao encontro do arrebatamento místico e poético, em vez de o combater. Ele reconciliará arte e ciência, mundo sensível e espiritual, natureza e história, sagrado e profano. Já no romance Os discípulos de Sais há uma série de correlações vertiginosas entre natureza, espírito, corpo e história que não podem ser feitas por um cientista. Só podem ser geradas pelo poeta, o único que compreende o sentido da natureza. O artigo pretende mostrar o quanto o ideal de reencantamento dos dois livros está ligado ao saber analógico renascentista que, segundo Hartmut Böhme, introduz uma semiologia da natureza baseada em vínculos de semelhança entre as coisas. Se, na Renascença, é o filósofo natural que decifra a assinatura das coisas, em Novalis é o poeta que faz da linguagem a chave do reencantamento e da liberdade. $\mathrm{O}$ artigo termina refletindo sobre o conflito entre ilusão e realidade na poesia moderna.

Palavras-chave: Novalis; poesia moderna; natureza; analogia; reencantamento.

Zusammenfassung: In Die Christenheit oder Europa schildert Novalis drei Etappen des historischen Werdegangs des Okzidents und verheißt die künftige Verschmelzung des Mittelalters

\footnotetext{
${ }^{1}$ Universidade Federal do Rio de Janeiro, Avenida Horácio Macedo, 2151, Cidade Universitária, Rio de Janeiro, RJ, 21941-917, Brasil. E-mail: edugbl@msn.com. ORCID: 0000-0002-5050-0957. Pesquisa realizada com bolsa de produtividade do CNPq.
}

\section{(cc) BY-NC}

Pandaemonium, São Paulo, v. 23, n. 41, set.-dez. 2020, p. 125-152 
LOSSO, E.G.B. - História, analogia e natureza em Novalis

mit der Aufklärung in Gestalt des gelehrten, deutschen Romantikers. In dessen Gestalt richtet sich das wissenschaftliche und aufklärerische Streben nicht weiter gegen die mystische und poetische Verzückung, sondern ist davon erfüllt; Sinne und Geist, Kunst und Wissenschaft, Natur und Geschichte, Heiliges und Profanes werden versöhnt. Schon im Roman Die Lehrlinge zu Sais bilden Natur, Geist, Körper und Geschichte ein außergewöhnliches Geflecht, welches sich nicht dem Wissenschaftler, sondern allein dem Poeten enthüllt, der den Sinn der Natur erfasst. Der Artikel erörtert, inwiefern das Inbild der Rückverzauberung in beiden Büchern dem Geiste der Renaissance verpflichtet ist. Die Renaissance begründete laut Hartmut Böhme eine Semiologie, die die Ähnlichkeiten der Dinge in der Natur in den Blick rückt. Während es allerdings in der Renaissance der Naturphilosoph ist, der die Signatur der Dinge aufschlüsselt, so ist es bei Novalis der Dichter, der sich durch die Sprache der Freiheit und Verzauberung der Welt eingedenkt. Am Schluss reflektiert der Text über die Spannungen zwischen Illusion und Realität in der Poesie der Moderne.

Stichwörter: Novalis; Moderne Poesie; Natur; Analogie; Rückverzauberung.

"Nós somos habitantes da floresta. Nosso estudo é outro. Aprendemos as coisas bebendo o pó de yakoana com nossos xamãs mais antigos"

Davi Kopenawa

\section{Religião e poesia moderna}

Estamos acostumados hoje a dissociar liberdade do escritor de religião. A literatura ganhou autonomia precisamente porque conseguiu se libertar das amarras da doutrina de qualquer instituição religiosa. Geralmente assinalamos, nas declarações de poetas do século XVIII e XIX, onde e quando eles demonstraram independência diante da moral cristã ou, quanto aos mais ousados, onde parecem tê-la provocado deliberadamente, como William Blake, no Matrimônio do céu e do inferno, Charles Baudelaire, em As litanias de satã, O Discurso do Cristo morto do alto do universo no sentido de que não existe Deus, de Jean Paul Friedrich Richter, e Uma estadia no inferno, de Arthur Rimbaud. Se o poeta é obediente ao cristianismo, onde estaria sua esperada ousadia? Temos a tendência a pensar que, se ele assim o for, não produz mais do que discursos pastorais.

É por isso que o ensaio de Georg Philipp Friedrich von Hardenberg, mais conhecido como Novalis, intitulado e canonizado como Cristandade ou Europa, de 1799, é considerado o seu momento mais fraco. Ele idealiza um governo medieval eclesiástico que harmonizava e unia homens simples. Estes viviam sossegados, sempre seguros de 
LOSSO, E.G.B. - História, analogia e natureza em Novalis

poder contar com a autoridade de governantes sábios, que "amenizavam e iluminavam os momentos mais conturbados da vida". Eles não permitiam que dissensos perturbassem a paz geral. Suas palavras suscitavam, por si mesmas, uma alegre obediência, pois a "maravilhosa beleza da Senhora da Cristandade" reluzia de sua fé infinita e contagiava todo o povo. Dos templos saíam tocantes imagens, doces fragrâncias, música exaltada, executadas por magníficas assembleias; as pessoas sentiam sua grandeza monumental, “carregada de mistério” (NovALIS 1991: 18).

Discursos inspirados e grandes rituais proporcionavam aos fiéis uma mistura de firmeza moral e encantamento estético. Ninguém desejaria obter algo a mais. A ingenuidade se justificava por tornar a sociedade feliz e pacífica. Esse é o quadro, ou melhor, o vitral colorido da Idade Média, descrito por Novalis. Ele não nega que essa perfeita simplicidade era frágil e indefensável. Neste momento os protestantes iniciaram mudanças: introduziram a leitura literal da Bíblia e a traduziram, vulgarizando-a. Em seguida, a frieza do saber mundano iluminista motivou um ódio contra o livro sagrado, depois contra os irracionalismos da fé, acusada de ignorância e, por fim, contra todo sentimento religioso. Isso levou a Europa à decadência. A principal nação responsável por esse estado de coisas foi a França.

Finalmente, Novalis introduz uma profecia: a anarquia da revolução francesa levará, inescusavelmente, a uma irresistível reação a si mesma, a um novo interesse pela religião, e o catolicismo voltará a dominar a Europa. Novalis observa que está em curso uma grande fermentação cultural, nas artes, na filosofia, nas ciências naturais, especialmente sediada na Alemanha. Se o entusiasmo religioso foi parcialmente banido, está em pleno vapor o entusiasmo intelectual, que, percebe-se, fermenta o potencial de resgatar o primeiro. Por conseguinte, tudo indica que haverá uma grande síntese entre indivíduo e sociedade, subjetividade e objetividade, fé e razão, espiritualidade e ciência, mística e crítica, sentimento e conhecimento. E que povo será responsável por esse heroísmo histórico? O alemão - por coincidência, os conterrâneos de Novalis. O reencantamento do mundo acabará com as guerras, inúteis e sofridas, entre as nações. Toda a corrupção da fé perpetrada pela arrogância dos eruditos, pela confusão das brigas políticas, chegará a um final feliz. No fundo, a erudição também está a serviço do desenvolvimento da humanidade e, num futuro reconciliador, tenderá para o lado da fé. Por fim, a ressurreição da religiosidade é a ressurreição da Europa. 
LOSSO, E.G.B. - História, analogia e natureza em Novalis

Saímos da leitura do "discurso" (Rede) decepcionados. Afinal, não foi o préromantismo alemão aquele que não só antecipou todo o movimento romântico europeu, inclusive francês, como ainda produziu uma reflexão filosófica que fundamentou as bases da crítica literária moderna, ultrapassando o paradigma judicativo? Não foi Friedrich von Hardenberg que, junto com Friedrich Schlegel, introduziu uma nova reflexão sobre a linguagem, que antecipou todo o linguistic turn das ciências da linguagem e da teoria da literatura do século XX? Podemos, inclusive, citar um trecho que mostra como Hardenberg havia já pensado a autorreferencialidade da linguagem e sua centralidade na poesia:

Se apenas se pudesse tornar compreensível às pessoas que com a linguagem se dá o mesmo que com as fórmulas matemáticas - Elas constituem um mundo por si — Jogam apenas consigo mesmas, nada exprimem a não ser sua prodigiosa natureza, e justamente por isso são tão expressivas - justamente por isso espelha-se nelas o estranho jogo de proporções das coisas. (NovALIS 1998: 195, do "Monólogo").

Aqui, vê-se como ele está chamando atenção ao fato de a linguagem não ser apenas mero apêndice da realidade, um instrumento de comunicação meio ineficiente, mas, ao contrário, ser um mundo especial, de rica expressividade, isto é, possuir um "espírito musical" que abre a possibilidade de se fazer a relação entre as coisas. A linguagem nunca é "pobre” mas sempre "universal demais", "inesgotável em melodias" (NovAlis 1998: 121), "um mistério tão prodigioso e fecundo", que "somente em seus livres movimentos a alma cósmica se exterioriza e faz delas um delicado metro e compêndio das coisas" (Novalis 1998: 195). Esse excesso de universalidade, esse veículo de exteriorização e "instigação" da alma ("a eficácia da linguagem em mim" NovALIS 1998: 196), esse espaço de medida e nomeação de tudo é misterioso e prolífico, mágico e musical, faz da linguagem a chave do reencantamento e da liberdade, e isso só é possível mergulhando em suas relações internas.

O ar messiânico de Cristandade ou Europa parece, de início, ter pouco a ver com tais insights. De qualquer forma, não há dúvida de que é um dos textos mais emblemáticos do romantismo. Ele contém boa parte das características enumeradas pelos manuais de história da literatura: nostalgia e idealização da espiritualidade medieval, recusa do mecanicismo, racionalismo e empirismo; repulsa ao espírito capitalista burguês; nacionalismo (ainda que, no caso alemão, seja sem nação, o que não deixa de ser uma ironia) que pretende incorporar uma "individualidade universal”; devaneios utópicos; visão escatológica da história. Não interessa ao romântico a realidade concreta, antes, o 
LOSSO, E.G.B. - História, analogia e natureza em Novalis

"mundo de possibilidades" da imaginação, e se ele for aberto pela linguagem, como vemos no trecho acima citado, tanto melhor.

Isso significa que, nesse trecho, onde encontramos um insight raro, o caráter autárquico da linguagem está ambiguamente ligado à liberdade do eu, seja para corroborálo, seja para ameaçá-lo com um fator impessoal que espelha tanto a objetividade neutra da matemática quanto o maravilhamento com o livro do mundo, isto é, os nexos entre as coisas. O arrebatamento místico com o movimento independente da linguagem despersonaliza o sujeito ao mesmo tempo em que o potencializa. Não seria insensato dizer que essa junção de matemática e encantamento, tornada um instrumento capaz de impor sua própria vontade ao sujeito, sua própria cadência, se assemelha ao terceiro momento sintético profetizado em Cristandade ou Europa. Por isso, mesmo as reflexões mais avançadas de Novalis estão ligadas ao horizonte hermenêutico da época, e o presente ensaio nos ajudará a entender algumas dessas contradições românticas.

\section{Proposta}

Novalis produziu uma obra poética que se tornou referência de toda a poesia moderna mais avançada, e é um precursor central da teoria literária do século XX. Ainda assim, como foi possível, no auge de sua produção, pouco antes de morrer, escrever um ensaio tão retrógrado e conservador? Essa é a pergunta que tantos especialistas se fazem, lamentando o deslize de nível. Especulações filológicas desconfiam que seu irmão mais novo, Karl von Hardenberg, poderia simplesmente ter inventado as partes mais suspeitas, há até os que duvidam do próprio Schlegel (que se converteu ao catolicismo em 1808; SCHIERBAUM 2002: 531-535). Contudo, a controvérsia do conservadorismo apareceu já quando o "discurso" foi lido no círculo dos românticos. O texto foi indicado por Schlegel para ser publicado na revista Athenäum. Goethe foi consultado e, como o grande poeta de Weimar não era afeito a apologias à religião, não recomendou a publicação. Isso significa que, por mais modificações que tivessem sido feitas posteriormente, a versão canonizada não está muito distante do que Novalis apresentou aos seus contemporâneos.

O grande erro de Cristandade ou Europa, especialmente aos olhos hodiernos, é investir a esperança utópica religiosa, católica, na história. Quem busca na história esperanças utópicas, é porque desistiu do pessimismo teológico diante da imanência. Não faz sentido juntar as duas áreas. Se ele sugere uma antecipação de certas visões 
LOSSO, E.G.B. - História, analogia e natureza em Novalis

escatológicas do marxismo, que depois farão história, seu gesto ainda trai a fantasia idealista. Isso sem contar seu descarado nacionalismo (sem nação) e eurocentrismo. Como hoje já passamos por uma série de estágios de desconstrução do eurocentrismo, vindas de dentro e de fora da Europa, sua aspiração por santificar almas europeias, para que elas se juntem a outros continentes e entoem cânticos sagrados como membros de uma única família religiosa soa indubitavelmente muito mal (NovALIS 1991: 49).

Aparecem estudiosos que, contudo, procuram demonstrar como as exaltações religiosas do pré-romântico estão intrinsecamente relacionadas ao seu avanço artístico e crítico, e que passagens brilhantes como a acima citada estão ligadas a uma concepção da literatura livre e autônoma, mesmo que seja, do mesmo modo, religiosa. Para isso, é preciso, sim, reconhecer o que se evidencia como ultrapassado nesse texto, mas ler nas suas entrelinhas traços pouco reconsiderados que, no meio das intenções conservadoras, passam despercebidos. Nesse sentido, é inevitável uma leitura analítica e interpretativa do imaginário que o fantasmagoriza, assim como uma leitura historiográfica de uma das primeiras propostas de interpretação histórica do destino europeu.

No Brasil, não era fácil entender, para muitos estudiosos laicos, como que Jorge de Lima e Murilo Mendes, em pleno modernismo, foram católicos engajados, fervorosos e conseguiram ser, ao mesmo tempo, ousados na forma, na linguagem e também no assunto, sem deixar de falar sobre temas e símbolos tipicamente místicos (LIMA 1968: 158, 247, 339; CANDIDO 1989: 188-189; ANDRADE 1953: 42). Tais casos se somam ao questionamento da tese da progressiva secularização da civilização e do desencantamento weberiano do mundo, que estava em alta até os anos 1960 (AGAMBEN 2011: 15-16). Ela começou a ser discutida não só diante da retomada de crescimento das religiões e sua importância geopolítica, mas também, como é o caso do nosso autor, de elementos oriundos da literatura mais progressista. Se, dentro da tese da secularização, casos como esses eram vistos como pequenas falhas, restos ainda comprometidos com o passado na trajetória de grandes nomes (ROMANO 1997: 67-70, 79-81, 87-92), eles passam a ser lidos a partir de uma visão menos linear e mais atenta à série de fatores delicados que permeiam a relação entre religião e esclarecimento, espiritualidade e cultura, desencantamento técnico e reencantamento da natureza.

Verificam-se duas propostas mais recorrentes, na bibliografia crítica, de abordar esse ensaio. Uma é fazer a leitura contextual dos pressupostos de sua filosofia da história, e da forma específica de síntese entre um modelo de desenvolvimento histórico 
LOSSO, E.G.B. - História, analogia e natureza em Novalis

progressivo e outro cíclico (KUSTER 1979; ZANUCCHI 2006: 71-75). Outra é estudar como sua estrutura é obediente a manuais de retórica da época (KUSTER 1979; ZANUCCHI 2006: 71-75). São estudos interessantes, uns bem filológicos, outros associados à filosofia da história. Não é o que faremos.

Aqui, nosso interesse se concentra numa interseção entre três áreas: estudos literários, estudos de religião (especialmente do aspecto místico) e estudos ecológicos, atualmente chamada de ecocrítica. Minhas questões são: que tipo de defesa da religião ele propõe; qual a relação da sociedade e da história humana com a natureza; qual o papel da poesia na mediação entre missão histórico-religiosa e natureza e, por fim, como essas noções estão inseridas no imaginário espacial romântico da Europa.

Por fim, pretendemos comparar a compreensão que o poeta adquire do sentido da natureza em Os discípulos de Sais com o esquema histórico de Cristandade e Europa. Com a ajuda de Hartmut Böhme, ressaltarei o papel da analogia na ligação intrínseca entre poesia e natureza.

\section{Antinomia e analogia}

Há um antagonismo de dois princípios que norteiam o discurso, em que um é defendido, outro é atacado. Novalis caracteriza os "membros da alta corporação" eclesiástica ou aristocrática como homens capazes de "piedoso recolhimento [göttlichen Betrachtungen, a tradução literal seria "contemplação divina"] do lado de dentro das solitárias paredes de um mosteiro". Eles buscam a "contemplação atenta do seu mundo interior" (zur aufmerksamen Betrachtung der innern Welt) (NovALIS 1991: 22; NovALIS 1977a: 509). Seu modo de vida ascético é explicitamente louvado. Embora tal ideal de vida seja nobre, houve um "cisma" (Spaltung) na história e ele foi "denunciado como fraude e ilusão" (als Trug und Wahn ausgeschrien) (Novalis 1991: 21; NovAlis 1977a: 509). Assim surgiu seu antagonista, o homem avaro, egoísta, que dirige todas "as aspirações apenas para o bem-estar material" (NovAlis 1991: 22; NovALIS 1977a: 509). Ele se ocupa tanto disso que não tem mais tempo para a contemplação: encontra-se sempre azafamado, à procura de saber e posse. Mais adiante, o autor fala da figura do erudito (Gelehrter), inimigo por excelência da "antiga organização clerical" (NovALIS 1991: 32; NovALIS 1977a: 515). À medida que o saber e a fé travam batalha, ele ganha terreno, e o "sentido do sagrado" é 
LOSSO, E.G.B. - História, analogia e natureza em Novalis

ressecado (die Vertrocknung des heiligen Sinns) (NovALIS 1991: 28; NovALIS 1977a: $512)$.

Nessa guerra entre "o antigo e o novo", onde estará a poesia? Novalis sempre associa o entusiasmo poético ao religioso. Quando o "poder secular tornou-se soberano, o sentido artístico sofre em consonância com o sentido religioso" (NOVALIS 1991: 28; Novalis 1977a: 512). O templo medieval é todo ornado com produções artísticas sublimes e piedosas. Quando os protestantes e, depois, os iluministas eruditos atacam a ingenuidade devota, a arte sofre tanto quanto a religião. A "obediência matemática" suprime "todos os vestígios do sagrado" (jede Spur des Heiligen zu vertilgen) e, embora se arvore de possuir a virtude da tolerância, na verdade impõe um espírito de neutralidade e indiferença à exaltação da fé e da poesia. O mundo se torna desencantado por um motivo muito simples: a luz do conhecimento científico não quer outra coisa senão "expurgar de todo e qualquer elemento poético a natureza e a terra que vivemos" (NovaLIS 1991: 34; NovALIS 1977a: 516). Novalis está exagerando? Afinal, o iluminista não é amigo das artes, inclusive lutando por sua independência? Novalis, sem dúvida, idealiza o catolicismo e força a mão para relacionar desenvolvimento artístico com governo clerical. Mas nota-se um momento de verdade em sua argumentação. Ele enfatiza que há um sentido estético que une estados místicos e poéticos, mas, com o avanço da matematização do mundo, com o paradigma mecanicista, é essa sensibilidade que começa a se perder.

Depois de nosso percurso em torno da dicotomia que ele constrói, fica mais claro, nessas passagens, qual o potencial crítico do romantismo novaliano. O exagero desse poeta em usar verbos fortes como "suprimir" (vertilgen) e "expurgar" (säubern) traços do sagrado é justificado ao repararmos como ele se insurge contra figuras que representam o futuro sucesso de um paradigma econômico, tecnocrático e administrativo - em termos atuais. A neutralidade do cientista e do burguês busca a dominação da natureza e, com todo atrevimento, cega os olhos a uma valorização estética de minúcias profanas, que, em termos românticos, são entendidos como "vestígios do sagrado", "elementos poéticos" da natureza. "A poesia contrasta na sua riqueza oriental com a desolada e fria Espitisberga desse saber de gabinete" (NovALIS 1991: 47). Ardor subjetivo e exótico não têm lugar na algidez objetiva do conhecimento.

Assim, o desenvolvimento histórico europeu resultou numa máquina de destruição da "beleza da fé", num empreendimento de extinção da poesia da natureza, 
LOSSO, E.G.B. - História, analogia e natureza em Novalis

aniquilamento do deslumbre espiritual. Percebe-se que geralmente a crítica moderna à religião separa o dogmatismo da fé do desinteresse estético para defender a autonomia da arte, mas Novalis os une indissoluvelmente, pois não enxerga na religiosidade senão qualidades artísticas e entusiásticas.

Chegamos a uma verdadeira antinomia, em que Novalis já tomou posição desde o início. A Europa começou muito bem e acabou muito mal. Sua origem é sublime e perfeita, o desenrolar da secularização é monstruoso e repugnante. Nada mais antimoderno, nada mais retrógrado - até aqui. Se Novalis terminasse o texto nesse ponto, não seria mais do que um mero tradicionalista, avesso a qualquer ideia de modernidade. Seria uma enorme contradição imaginar que um dos grandes precursores (junto de Edgar Allan Poe) dos fundadores da poesia moderna (Baudelaire, Rimbaud e Mallarmé), segundo Hugo Friedrich (1978: 141), não fosse mais do que um conservador dicotômico.

No entanto, precisamos fazer algumas observações que irão abalar a dicotomia. Embora Novalis defenda, essencialmente, a era medieval, e ataque os protestantes, há um elemento quase não abordado por ele que está por trás de boa parte de tudo o que diz sobre beleza espiritual, poesia e natureza. Trata-se da filosofia hermética renascentista, da qual foi leitor assíduo e compenetrado. Ele se refere a ela rapidamente, de forma positiva, quando cita as misteriosas sociedades secretas (alusão aos Rosacruzes, NovALIS 1991: 56) e Jakob Böhme (1575-1624), o teósofo mais dileto dos românticos, autor da Assinatura das coisas (Signatura rerum, BÖHME 2009). Em seu painel histórico, Böhme é, junto com os jesuítas, uma estrela solitária (ainda que formando em torno de si uma “pequena comunidade", segundo Novalis) de reencantamento cósmico em meio à marcha da literaridade e vulgaridade protestante (Novalis 1991: 28). Porém, sabe-se que Böhme não foi tão solitário em seu tempo: desde Marsilio Ficino (1433-1499), há toda uma filosofia renascentista que releu e reinterpretou Platão junto ao lendário Hermes Trismegisto, deus de nome grego mas de origem egípcia (que remonta ao deus Toth), suposto autor do corpus hermeticum. Segundo Frances Yates, a partir de Ficino, houve todo um movimento cultural que buscou a formulação de uma magia reformada e erudita (YATES 1995: 13-32). Tais filósofos, como Giordano Bruno (1548-1600), ousaram propor uma reforma mágica da Igreja a partir do que Foucault chamou de "saber da semelhança" (Foucault 2000: 24). Pelo destino de Bruno, condenado pela inquisição à morte na fogueira, em 1600, já se sabe que eles fracassaram. Mesmo assim, seu legado se espalhou pela Europa, e o chamado “idealismo mágico" de Novalis é um de seus mais importantes 
LOSSO, E.G.B. - História, analogia e natureza em Novalis

herdeiros (é o que defendem BERGENGRUEN 2003: 39-42 e BÖHME 1988: 25, 40-41, 97 $115)$.

Portanto, quando Novalis caracteriza os encantos da era medieval, está se referindo, sub-repticiamente, a toda uma linhagem que vai de nomes da filosofia antiga, como Plotino (205-270), e medieval, como Pseudo-Dionísio Areopagita (Corpus Dionysiacum, escrito entre 485 e 528), até Marsilio Ficino (1433-1499), Heinrich Cornelius Agrippa (1486-1535), Paracelso (1493-1541), Giordano Bruno (1548-1600), chegando a Jakob Böhme (1575-1624), isto é, ao neoplatonismo cristão e renascentista. Novalis tem grande simpatia por diferentes manifestações da espiritualidade: o ascetismo, a mística cristã e o hermetismo, mas a influência neoplatônica, com sua cosmologia anagógica e analógica, perpassa todos eles. Nas passagens que vimos, ele se refere à capacidade de interiorização e recolhimento, exercícios poético-analógicos e admiração pela estética eclesiástica. Não é à toa que todo esse olhar estético para as belezas da Igreja dará frutos na poesia simbolista, pois, para ela, a Idade Média conservava o sentido do símbolo, o acesso a "camadas superiores da alma" (Michaud 1961: 19), ou seja, no simbolismo verifica-se o segundo momento de uma nostalgia romântica medieval, com aspirações espirituais. A mistura do meio esotérico com o meio poético no fin de siècle francês tinha Novalis como uma de suas leituras diletas (MichelET 1890: 9; MichAUD 1961: 21-23, 469). Só para ficar com um exemplo da literatura brasileira, encontram-se vários poemas de Cruz e Sousa que devaneiam sobre as esculturas das catedrais, com seus Cristos e anjos (CRUZ E SousA 1995: "Cristo de Bronze" 67, "no recolhido silêncio de igrejas góticas" 460, "Glória en Excelsis" 475-476, "Artista sacro" 490-492).

Se o neoplatonismo medieval e renascentista comparece subterraneamente no texto, a famosa referência de Novalis da "varinha mágica da analogia" (Zauberstab der Analogie) como instrumento de leitura dos segredos da história, introduz, aqui, elementos que não estão na Renascença. "É para a História que vos remeto; procurai nesse tecido rico de ensinamentos os momentos idênticos e aprendei a manejar a vara mágica da analogia" (NovAlis 1991: 37; NovALIS 1977a: 518; KREMER 2008: 467).

Esse uso da analogia na história vem já de Hamann, Herder e chega a Schiller. Logo, faz parte de um historicismo pós-iluminista. Mas o seu caráter "mágico" acentuado por Novalis, emblematizado numa expressão muito usada por ele e Schlegel, Zauberstab, reforça, sem dúvida, a raiz neoplatônica da figura da analogia dentro das correlações da filosofia da história, o que é um complexo epistemológico rico de sugestões: as relações 
LOSSO, E.G.B. - História, analogia e natureza em Novalis

de semelhanças que os alquimistas e filósofos ocultos do Renascimento buscavam entre as coisas e as esferas, o filósofo poeta romântico busca na leitura das relações enviesadas de fenômenos históricos. Não é preciso insistir que essa hipótese foi singularmente explorada por Walter Benjamin, tempos depois, ligada a sua interpretação do fragmento alegórico de Novalis (SELIGMANN-SILVA 1999: 92-93). O uso da varinha, como usualmente se sabe na forma como a indústria cultural de filmes fantásticos de inspiração medieval divulga (como Harry Potter), está ligado à magia, mas as fontes renascentistas falam frequentemente na relação entre feito mágico e adivinhação: “A fé põe em suas mãos a varinha mágica da adivinhação, faz apagar as velas, girar as chaves, atrai as tesouras e faz rodar o cernidor" (PARACELSO 1973: 416), "havia uma estátua [em Dodona, Grécia arcaica] segurando uma varinha que batia em uma vasilha, a qual dava respostas por meio de toques moderados" (AGRIPPA 2008: 802). Percebe-se que, se a fé (que "remove montanhas") é capaz de adivinhar e fazer prodígios e se a estátua é capaz de responder a questões sobre o futuro com a varinha devido ao balanço feito pelo vento, segundo os magos filósofos, em Novalis o olhar deles para o futuro pode ser deslocado para o passado e fazer prodígios interpretativos, isto é, revelar sentidos ocultos da história por meio de analogias. Nesse caso, a analogia é o instrumento mágico, a varinha intelectual do historiador. No entanto, Novalis também não é menos pretensioso em relação a visões de futuro.

\section{Síntese}

Depois do diagnóstico de decadência da Europa, do ponto de vista de um "observador objetivo", o estado de dissenso anárquico que se instaurou faz brotar, de seu próprio declínio, a "ressurreição da religiosidade" (Novalis 1991: 36; NovALIS 1977a: 517). O ensaísta cria esse personagem hermenêutico determinado para que ele, no diagnóstico da situação, chegue a uma conclusão que é perfeitamente favorável a sua maior paixão. É da própria crise da religião que ele vê despertar a "vingança da face interior da humanidade, de sua face criadora, do seu caráter ilimitado, da sua infinita variedade, da sua natureza sagrada" (NovALIS 1991: 40).

Mas não é só do declínio que surgirá a revanche dos valores elevados. Todo o empenho iluminista, todos os seus estragos e mesmo sua injustiça com a fé serão justificados porque, nesse estágio, haverá uma reconciliação entre os inimigos, e aquilo

Pandaemonium, São Paulo, v. 23, n. 41, set.-dez. 2020, p. 125-152 
LOSSO, E.G.B. - História, analogia e natureza em Novalis

que fez com que um enfraquecesse o outro vai se reverter em potencialização recíproca. Assim como Novalis mistura magia com teologia mística (ligação que advém do ocultismo renascentista, por exemplo em Paracelso a medicina está nascendo da magia e é acompanhada pela teologia: "Porque assim como o corpo é o domicílio da alma, a teologia e a medicina devem caminhar juntas, iluminando-se mutuamente", PARACELSO 1973: 195), ele agora nos diz que se o Estado revolucionário secular quiser se sustentar, precisa se unir “às alturas celestes” (NovALIS 1991: 37), isto é: não há Estado sem uma nova religião, "uma aspiração mais elevada" que deve, naturalmente, retomar a força e os ideais da antiga religião. Não há poder terrestre sem ajuda do poder divino.

Se, na França, a religião é vista por Novalis como privada do direito de cidadania, é na Alemanha que se delineia "uma época superior na formação dos homens", o que a levará a "uma grande preponderância sobre os outros povos". A Alemanha é capaz de juntar aquilo que a França separou, ela pode abraçar os antigos monumentos da história e fecundá-los "com renovada paixão" (Novalis 1991: 39). Em suma, nesse futuro promissor, o entusiasmo científico e filosófico irá ao encontro do arrebatamento místico e poético, em vez de o reprimir, de o perseguir, de o estrangular.

Novalis chega ao ponto de usar uma típica imagem da mística nupcial (Brautmystik) para profetizar a vinda do novo messias, que não é outro senão a nova humanidade. Diz que ele nascerá do abraço da "jovem Igreja maravilhada" com "o seu Deus amantíssimo" (einer jungen überraschten Kirche und eines liebenden Gottes) (Novalis 1991: 40; Novalis 1977a: 519). Desde a homilia de Orígenes (185-254) do Cântico dos Cânticos que a união mística de Deus com seu povo se estabeleceu solidamente interpretada no cristianismo (antecedentes judaicos e no próprio Novo Testamento são vários, por exemplo, Paulo em Efésios 5:23; OrIGÈnE 1953: 11, 14). Nesse ponto, fica mais explícito todo o erotismo místico que atravessa a imagética criada no discurso. Agora se percebe que o tom revoltado e denunciatório do segundo momento era o preparo para uma erotização espiritualizada das promessas do futuro, cujos vestígios já estão em curso no desenvolvimento da cultura alemã. Essa “era profética” será capaz de alcançar a cura mágica do passado e do presente: conseguirá “operar milagres" e "sarar feridas" (NovALIS 1991: 41).

A essas alturas, uma imagem semelhante à dos governantes medievais é usada para caracterizar o trabalho dos intelectuais: eles são os "anacoretas do deserto do entendimento" (Novalis 1991: 42). Agora são vistos como ascetas do saber, que 
LOSSO, E.G.B. - História, analogia e natureza em Novalis

renunciaram a todo prazer, inclusive à "beleza da fé", para edificar um tempo em que ela vai ressurgir com firmeza e segurança. Eles anunciarão, portanto, a "sacralidade da natureza, a infinita liberdade da arte, a necessidade do saber, o respeito pelo mundo sensível e a onipresença da verdade da história" (die Heiligkeit der Natur, die Unendlichkeit der Kunst, die Nothwendigkeit des Wissens, die Achtung des Weltlichen, und die Allgegenwart des wahrhaft Geschichtlichen) (Novalis 1991: 42; Novalis 1977a: 520). Eles reconciliarão arte e ciência, mundo sensível e espiritual, natureza e história, sagrado e profano. Se, nos tempos iluministas, o segredo da natureza se resguardava no seu íntimo mistério, se ela se mantinha "maravilhosa e incompreensível", “poética e infindável” (NovALIS 1991: 32), impassível a tentativas de mecanizá-la, agora ela revela sua essência sagrada, pois eruditos dos nossos tempos possuem o "sentido religioso" e "artístico". Assim, eles veneram os monumentos da fé e respeitam o mundo sensível, ocupam-se das coisas externas e da interioridade, somente eles são capazes de produzir a espiritualização das ciências e a concretização sensível da fantasia e do sagrado. Só nesse estágio se evidencia como havia beleza estética na experiência religiosa e valor espiritual na experiência poética. O que a filosofia renascentista analógica já tinha proposto e praticado pouco tempo antes do nascimento da ciência experimental, Novalis quer reatualizar, depois da ruptura iluminista. Aos olhos desse filósofo romântico, a religião não prejudica a autonomia da poesia; ao contrário, é a própria predisposição artística que se revela nos arrebatamentos místicos. Assim, o impasse que foi colocado no início deste artigo, do antagonismo entre religião e poesia moderna, encontra agora uma resposta do autor. Novalis propõe um ataque à neutralidade burguesa e empírica, de modo a produzir uma fantasia filosófica e profética onde o canto poético e religioso, são, no fim das contas, reconciliados, readmitidos e celebrados conjuntamente com os avanços técnicos. Retomando o trecho do "Monólogo" citado acima, a comparação da autorreferencialidade da linguagem com "fórmulas matemáticas" faz mais sentido agora: a reconciliação entre religião, poesia e ciência se dá no espelho em que a linguagem (especialmente usada pelo poeta) transparece do "estranho jogo de proporção das coisas". Em outras palavras, se a ciência eliminou a assinatura das coisas, ela pode também contribuir para seu ressurgimento se se aliar ao saber da semelhança (afinal, na linguagem "a alma cósmica se exterioriza e faz delas um delicado metro e compêndio das coisas", NovALIS 1998: 195), impregnado na autorreferencialidade da linguagem, ou, em termos piercianos, no caráter icônico do signo. 
LOSSO, E.G.B. - História, analogia e natureza em Novalis

Quando Novalis afirma que a "física atingiu seu apogeu" está se referindo aos trabalhos científicos de Goethe. Ele o considera "o primeiro entre os físicos do seu tempo" (Novalis 1991: 44), porém, aos olhos de hoje, Goethe está muito longe de ser um cientista. Segundo Hartmut Böhme, no seu livro Natur und Subjekt, Goethe também era leitor entusiasta da filosofia renascentista e tentou retomar alguns desses princípios em seu tempo. Por isso mesmo o professor de Teoria da Cultura da Universidade Humboldt de Berlin afirma que Goethe se coloca numa posição marginal de defensor de um paradigma passado e busca resgatar seus traços perdidos (BöHME 1988: 147). Ele pretende introduzir uma experiência científica que, em vez de se separar da objetividade natural, possa se colocar como parte da "natureza vivente" "em ligação com o todo (GOETHE 1851: 322; BöHME 1988: 153, sempre que citamos obra de outro idioma a tradução é nossa). O que Novalis vislumbra como o prenúncio da futura vitória da conciliação entre ciência e experiência estética revelou-se um delírio de mais um poeta que se intromete em assuntos científicos.

Isso quer dizer que, infelizmente, a ciência dura não foi "contagiada pela chama da vida eterna" (NovAlis 1991: 40). O poder da magia poético-musical, do qual Novalis é tão devoto, do qual retira toda sua formidável musicalidade verbal, não foi capaz de influenciar em nada o desenvolvimento da ciência, muito menos o destino da humanidade; não, pelo menos, nos termos messiânicos por ele colocados.

Vale observar, com isso, como todo o esforço atual dos estudos ecológicos de reformular a separação entre cultura e natureza ganha algum sentido num ensaio romântico idealista que pretende reconciliar racionalismo e subjetividade, exterioridade e interioridade, civilização científica e experiência poética da natureza (RIGBY 2017: 111128). Hoje, observa-se quanto esforço a antropologia faz para mostrar que a cosmovisão indígena produziu uma cultura não predatória, uma sensibilidade que não desmata florestas, mas as multiplica (KOPENAWA 2015: 52, veja a descrição de Bruce Albert da última parte de A queda do céu: "Este último relato, construído na forma de uma série de viagens xamânicas, é entremeado com meditações comparativas a partir de uma etnografia crítica de certos aspectos de nossa sociedade" isto é, é um olhar de fora do mundo civilizado, "e desemboca numa profecia cosmoecológica sobre a morte dos xamãs e o fim da humanidade"). Isso, inclusive, lembra um trecho de Heinrich von Ofterdingen (1800), o trecho em que se afirma que, no passado, os homens experimentavam vida e sentido intenso na natureza. $\mathrm{O}$ saber dos sinais das estrelas e da natureza são uma ciência 
LOSSO, E.G.B. - História, analogia e natureza em Novalis

do mistério, abrem a "vida secreta das florestas" (NovALIS 1998: 107; NoVALIS 1977b: 211).

\section{Sentido da natureza}

Se há em Novalis um núcleo de resistência à dominação da natureza, que é interessante reler sob um olhar epistemológico atualizado nas questões do antropoceno (RIGBY 2017: 111-128), teóricos como Hartmut Böhme defendem que é em Heinrich de Ofterdingen que ele está mais claro, ao expor uma relação com as montanhas e a mineração voluntariamente desvinculada de frios propósitos extrativistas. No entanto, uma defesa da valorização poética da natureza está mais clara no romance Os discípulos de Sais. Nele, uma ambientação egípcia lendária indiretamente acompanha a adoração renascentista à sabedoria hieroglífica do Antigo Egito (YATES 1995: 17-18, adoração do Egito em Giordano Bruno: 241-242, 251-252) mediada pela herança de Atlântida que Platão, no Timeu, atribui aos sacerdotes de Sais (BLUMENBERG 1989: 246-247; YATES 1995: 494). O romance mostra a relação entre um mestre e seus discípulos na localidade de Sais, sendo o narrador um deles. A ideia da cidade vem da tradição neoplatônica da leitura desse trecho de Timeu: "Há no Egipto - começou Crítias -, no extremo inferior do Delta, em redor da zona onde se divide a corrente do Nilo, uma região chamada Saiticos; e da maior cidade dessa região, Sais" (PlatÃo 2011: 22e, 81; ver a leitura da Atlântida pelo neoplatonismo renascentista em FICINO 2010: 5; VIDAL-NAQUET 2007: 56).

Segundo Mario Zanucchi, a escolha de ambientar um diálogo sobre poesia e natureza no Egito está ligada à polêmica que Johann Gottfried von Herder (1744-1803) travou com Johann Joachim Winckelmann (1717-1768). Em Geschichte der Kunst des Altertums (1764), Winckelmann defendia que a arte egípcia não desenvolveu a beleza: ela se enrijeceu na representação dos deuses e apresentou um reconhecimento social deficiente dos artistas, sem o desenvolvimento de academias, como se comprova a existência delas na Grécia (ver a primeira parte do segundo capítulo "Von der Kunst unter den Ägyptern”, WINCKELMANN 1825: 141-256). O jovem Herder, em algumas obras de sua primeira fase, como Auch eine Philosophie der Geschichte zur Bildung der Geschichte der Menschheit e Ältesten Urkunde des Menschengeschlechts (1774), defende que o modelo de Orfeu vem de Hermes e, mais arcaicamente, de Toth. Egito e não Grécia é, para ele, a origem do mundo ocidental (ver o capítulo “Ägypten”, HERDER 1965: 80- 
LOSSO, E.G.B. - História, analogia e natureza em Novalis

88). Entretanto, essa fascinação pela estética oriental dura somente de 1769 a 1777 , depois, ele não se refere mais a ela. Novalis, contudo, é um sucessor do jovem Herder nesse sentido: sua ambientação de uma discussão sobre poesia e natureza em Sais mostra que ele corroborava a tese da influência dominante do Egito para os gregos e reconhecia um "elemento oriental-dionisíaco de entusiasmo no caráter originário do helenismo" (ZANUCCHI 2006: 334-336). A proximidade de uma sabedoria oriental com a natureza é utilizada para ambientar uma reflexão poética de grande alcance. Vale mencionar como o Ocidente, grego e europeu, já nessa época, é associado à racionalidade e à subjugação da natureza, enquanto o Oriente seria um lugar de refúgio de uma sabedoria arcaica e tradicionalmente profunda. Mais importante ainda assinalar que o iluminismo, nesse caso, toma para si o destino utilitarista do Ocidente e apaga anseios teosóficos do Renascimento. Se em Cristandade ou Europa o saber da semelhança renascentista quase não se vê, na ambientação lendária dos Os discípulos de Sais ele está estabelecido como algo ao mesmo tempo subterrâneo e onipresente. O que é apresentado - o Egito - é uma imagem arcaica que reflete o saber renascentista oculto, que, por ter sido desconsiderado pelo século XVII e XVIII, deixou de ser “ocidental”, já se tornou um Oriente dentro do próprio Ocidente.

O uso espacial de uma cidade de culto para um diálogo filosófico entre discípulos pretende vitalizar, romantizar a filosofia com sua dramatização (LEUSING 1993: 76), seguindo aqui a origem dialógica platônica, assim como, por outro lado, dar a um romance o objetivo da busca da sabedoria. A palavra "Sais", inclusive, ao ter menos características concretas de descrição do que sugestão lendária, cria uma singularidade de dimensão sonora no seu vazio contextual (LEUSING 1993: 78-79). Inclusive, Leusing observa que a palavra Sais "é uma mistura de signo e imagem acústica da palavra da deusa Isis" (LEUSING 1993: 79). Eu diria que é quase um anagrama.

Por conseguinte, não há propriamente enredo: o romance é um ensaio em que as reflexões sobre a natureza são apresentadas em diferentes monólogos de personagens, que são discípulos viajantes ao encontro do mestre, sendo a cidade de culto um ponto de encontro nuclear de peregrinos.

Na segunda parte, intitulada "Natureza", o narrador demonstra o desejo de "recuperar, à vontade, o estado natural primitivo" que foi perdido por "homens recémchegados" que dividem o interior e o enfraquecem. O que pode fazer com que essa recuperação ocorra é "voltar a misturar as cores internas do seu espírito" de modo que ele 
LOSSO, E.G.B. - História, analogia e natureza em Novalis

consiga interligar de novo cada parte separada (NovALIS 1989: 39). A divisão do interior deve ser combatida com a mistura de pressentimentos internos.

Essa é a solução para o problema que foi apontado no início do livro (na primeira parte, "O discípulo"): por trás da diferença de percursos dos homens, há "figuras" nos mais diversos fenômenos materiais, que são arrolados na forma de uma enumeração caótica: "na neve, nos cristais, na forma das rochas" etc. A beleza de cada figura delineia uma "escrita miraculosa" (Wunderschrift, aqui discordamos da tradução Luís Bruhein, “escrita singular”) e levanta o pressentimento (Ahndung, que na forma mais corrente atual seria Ahnung) de uma chave que, contudo, não se revela. Novalis emprega um termo alquímico inventado por Paracelso, Alkahest (líquido tido como dissolutor de todas as substâncias, que motivou tanto especulações de alquimistas quanto do nascimento da química no século XVII, mais detalhes em JOLY 1996: 305-344), que serve como metáfora para a purificação das sensações que ora se fixam em desejos e pensamentos, ora desaparecem da atenção no instante seguinte: "Dir-se-á que um alcahest qualquer se espalhou nos sentidos dos homens com desejos e dores que aparentam fixar-se, apenas por momentos, numa rigorosa forma". Se primeiramente há adensamento da percepção, conduzido pelo Alkahest alquímico dos sentimentos purificados, em seguida há dissolução: “Assim nascem os seus pressentimentos; mas não tarda que à frente dos seus olhos, como outrora, tudo comece a girar" (NovALIS 1989: 31-2).

A incapacidade de decifração está ligada à dissociação do interior. O pressentimento é uma sensação de reunificação para o encontro de um sentido, que, contudo, é perdido, por causa da decadência profana de nossa atenção, que associa a dispersão do pensamento com a compartimentalização da racionalidade científica. A possibilidade de superar o mero pressentimento e, numa leitura concentrada da natureza, decifrá-la, está em outra ideia do médico alquimista.

Paracelso é autor de uma afirmação bem inusitada: "Portanto Deus permanece sendo o maior escritor em todas as coisas, o primeiro, o mais elevado e fonte de todos os nossos textos" (PARACELSUS 1970: 77). A metáfora do livro do mundo vem de muito cedo e não é novidade. No campo cristão, foi estabelecida por Santo Agostinho (Blumenberg 1989: 29-31, 48-56), mas Paracelso aqui caracteriza Deus de forma bem precisa como "escritor" de "textos" (BLUMENBERG 1989: 69). Esse é o pano de fundo do Wunderschrift de Novalis logo nas primeiras frases de seu romance (BLUMENBERG 1989: 246-250).

Pandaemonium, São Paulo, v. 23, n. 41, set.-dez. 2020, p. 125-152 
LOSSO, E.G.B. - História, analogia e natureza em Novalis

Hartmut Böhme publicou um livro chamado Natur und Subjekt, em 1988, que é central para todas as questões que estamos tratando, pois foi um precursor do que hoje é chamado de ecocrítica e abriu a possibilidade de ler a tradição europeia com a problemática ecológica (GOODBODY 2007: 19, 30, 257-260; RigBY 2017: 115-116). Ele afirma, justamente, que, quando Paracelso introduz Deus como autor do livro do mundo, ele se torna o ponto de comutação de "uma filosofia semiótica da natureza". "Paracelso é o primeiro que estabelece como programa de uma pesquisa da natureza profana o conceito teológico de lingua naturae", isto é, "o espaço integral da criação divina é reconstruído pela semiologia paracelsiana da 'luz da razão"”. Não é uma razão experimental nem matemática, é a razão que decifra a assinatura das coisas por meio de uma semiologia conduzida pela semelhança de aparências, ou seja, é uma razão gnóstica que se alia à magia, em vez de rejeitá-la. Essa formulação mantém-se como grande influência não só para medicinas alternativas (homeopatia) como "para uma forte corrente subterrânea de mística natural e fisionomia natural da Renascença até o tempo de Goethe”. Mas é no romantismo de Novalis que tal influência "vai se transformar no conceito de 'linguagem da poesia"" que "busca traçar o 'livro absoluto' para onde a 'escrita cifrada da natureza' e a 'linguagem do poeta' devem convir' (BöHME 1988: 25). O que as medicinas alternativas transpuseram para uma atualização moderna do programa paracelsiano, a estética romântica conduziu para uma decifração especificamente poética, em que a semiologia medicinal se converte no elo íntimo da escrita natural com a linguagem poética.

Hartmut Böhme traça, então, em termos gerais, a trajetória filológica que estamos observando num ponto bem específico do romance. O que Novalis entende como capacidade dos homens antigos, perdida pelos homens modernos, e que deve ser resgata modernamente, foi postulada por Paracelso, com precisão, como programa de filosofia natural, nas bases pré-modernas renascentistas. Isso não significa outra coisa senão que os antepassados não são tão arcaicos assim, apenas estão no momento imediatamente anterior à "idade clássica" racionalista e iluminista de divisão e enquadramento de saberes de que fala Foucault, o que só evidencia o abismo da ruptura que se formou com o advento do paradigma taxinômico da ordenação da empiricidade feita de "uma representabilidade geral do ser e o ser manifestado pela presença da representação". A ontologia do pensamento dos séculos XVII e XVIII postula que "o ser é dado sem ruptura à representação" (FOUCAULT 2000: 285), ao passo que na do Renascimento não há tal 
LOSSO, E.G.B. - História, analogia e natureza em Novalis

transparência nem equivalência, há simpatias e similitudes. A idade clássica busca a exatidão instaurada por um "sistema de signos que fosse transparente à continuidade do ser" (FOUCAULT 2000: 287), a semiologia paralcesiana busca a assinatura, a cifra sagrada da concretude profana.

A semiologia novaliana, por consequência, reage contra a ordenação empírica clássica transfigurando a assinatura à serviço da redescoberta e recriação poética do mundo. Nesse caso, a crítica ao iluminismo que vimos em Cristandade ou Europa, que obliterou o Renascimento na oposição entre Idade Média e Iluminismo, se repete em $O s$ discípulos de Sais numa oposição ainda mais geral entre homens primitivos e homens de saber que perderam a sabedoria, os quais, por sua vez, serão o lado destruidor da natureza, enquanto o poeta é aquele que resguarda e resgata vínculos primordiais (NOVALIS 1989: 41). Os homens empíricos "dividiram e transformaram essa ilimitada Natureza em elementos diferentes [...] procuravam descobrir, a machado e à enxada, a estrutura interior e as relações entre as diversas partes". Conclusão: "Fizeram, estes últimos, a amiga Natureza perecer" pois quem só a procura sem "amor de coração inteiro", só "para ampliar os seus conhecimentos", não frequenta outros lugares senão "os hospitais e os ossuários". Em contraposição, "mas para o poeta ela [a natureza] reviveu como se um vinho generoso a reanimasse pelos mais calmos e divinos sons", pois os espíritos sonhadores "se interessavam, sobretudo, pelas coisas fluidas e fugidias", é o poeta, então, que "entrega o seu maravilhoso coração" dedicado a conhecer sua "alma a fundo" (NovAlis 1989: 41). Essa passagem evidencia que toda a ambientação lendária do romance não perde a chance de expor uma franca crítica ao ordenamento estrito das identidades, à dissecação cadavérica no experimento da natureza buscando somente o que é repetível. E não há como conceber tal crítica, tal origem da crítica ao cientificismo, senão a partir daquela episteme que a ciência combateu e silenciou: a ordem da semelhança.

A dissociação psíquica vinda da compartimentação de saberes e interesses não ocorria no homem primitivo. Como "à natureza da sensação corresponde a natureza do sentido", nossos antepassados harmonizavam uma com a outra e possuíam um conhecimento mais profundo da natureza e do espírito (NovALIS 1989: 40). Novalis defende a busca de conformidade entre a história do universo e a do homem, de modo que "o caráter acidental da Natureza" não esteja afastado da "Natureza humana", isto é, a natureza deve ser considerada "como criatura humana" para ser mais "inteligível". 
LOSSO, E.G.B. - História, analogia e natureza em Novalis

Quem é capaz de entender a natureza tão bem quanto um homem, como se fosse um próximo, com o qual pudesse confabular? O poeta.

Por isto mesmo foi a poesia o instrumento favorito do amigo da Natureza; e nos poemas é que mais claramente surgiu o seu espírito. Quando lemos ou escutamos um verdadeiro poema [ächte Gedichte], sentimos que uma inteligência muito íntima da Natureza se perturba [innern Verstand der Natur sich bewegen]; e ao mesmo tempo nela, e por cima dela, flutuamos como um corpo celeste. (NovALIS 1989: 40; NovALIS 1977b: 84)

Não é possível, então, entrar em comunhão real com a natureza sem exercitar a sensibilidade poética. Um genuíno (ächt) poema transmite o entendimento interno (innern Verstand) da natureza. Só assim o homem é capaz de imergir na natureza e elevarse, ao mesmo tempo. Mergulho e ascensão são um mesmo deslocamento sublime, não se diferenciam: "e se o desejo insatisfeito quiser levantar-se a alturas imensas, há-de o ditoso amor comprazer-se numa descida às profundidades sem fim" (NovALIS 1989: 75). Assim como a analogia é a varinha mágica da leitura cifrada da história, a poesia é o instrumento da philia do homem com tal physis romântica. O entendimento dos segredos naturais é possível com o desenvolvimento de um dispositivo pessoal interno: "ninguém pode compreender a Natureza se não possuir o necessário órgão, o instrumento interior que cria e analisa" (NovALIS 1989: 75). Observa-se a instrumentalização do ininstrumentalizável: analogia e poesia são práticas intelectuais que, em vez de servir à dissecação da matéria, anseiam a reunificação com o cosmos, isto é, a totalidade do tempo (história) e do espaço (natureza) a partir da associação de suas partes (acontecimentos e coisas). A aproximação dos componentes que habitam o que Kant chama de formas puras da intuição sensível (espaço e tempo) pretende recuperar a totalidade universal que o filósofo de Königsberg via como inacessível.

Mais próximo do final do romance, no meio de um diálogo intenso entre os discípulos, um recém-chegado diz que é preciso tanto dar "o máximo de atenção à totalidade daquilo que executa", para que os pensamentos tomem forma, quanto dividir, por causa deles, a atenção “deixando-a vaguear à vontade”. É nessa variabilidade flexível de atenção e distração que "o homem descobre a sua real e específica liberdade", quando "o mundo exterior faz-se transparente, e o interior complexo e cheio de significado" (Novalis 1989: 62). A preocupação com o exercício de diferentes modos de apreensão dos fenômenos naturais mostra a importância, para Novalis, do treino do olhar para a alteração da percepção, em que o material e o espiritual, o exterior e o interior, devem criar um vínculo: "Deste modo o homem passa a um vivo estado íntimo entre dois 
LOSSO, E.G.B. - História, analogia e natureza em Novalis

mundos, na mais completa liberdade e em suave consciência da força que tem" (NovALIS 1989: 62). Liberdade, intimidade e potência são indissociáveis de um pensamento extenso e profundo, intenso e delicado.

Tal prodígio do estado poético não cansa de "perseguir estas associações dos dois mundos, nem de procurar conhecer-lhe as leis, as simpatias e as antipatias" (NovALIS 1989: 63). Vê-se em toda essa reflexão que as simpatias e antipatias entre as coisas e as esferas estão em primeiro plano. Um dos grandes nomes da filosofia renascentista, Henrique Cornélio Agrippa, no primeiro livro do De occulta philosophia, de 1531, esclarece: “Ora, essa espécie de atração por meio da correspondência mútua das coisas entre si, de superiores com inferiores, os gregos chamavam de $\sigma 0 \mu \pi \alpha ́ \theta \varepsilon ı$ " (AGRIPPA 2008: 202). Percebe-se uma empolgada busca das leis que regem as associações entre os extremos universais, em outras palavras: é a clara retomada da busca de uma gnose, que anseia leveza e poder, prazer e soberania, inocência e sabedoria.

A locomoção ágil e inopinada entre corpo, espírito e natureza implica uma sensação de liberdade e suavidade em que não mais se vive o mundo como algo estranho. Pelo contrário, "logo the parece estar no universo como em sua casa" (NovALIS 1989: 62). Como diz Octavio Paz: "É explicável: a analogia torna o mundo habitável" (PAZ 1984: 93). É a experiência da utopia realizada: a superação da alienação, no sentido estrito do termo. Porém, não deixa de ser um treinamento poético constante. O poeta não cansa, mas também não é passivo: é impelido sempre para um encontro associativo novo, um novo convite para o jogo sem fim. A descoberta da interioridade é uma exploração da afinidade entre diferentes intimidades. Tal ocupação não se esgota porque dá prazer, especialmente devido à animação do devaneio: "bem-vindo quem souber tecer uma nova fantasia sobre as coisas" (NovALIS 1989: 65). Estudo e desfrute não se opõem, alimentam, simultaneamente, a expansividade do entusiasmo: "quem possuir o sentido da Natureza e o tiver exercitado, disfruta-a ao mesmo tempo que a vai estudando, e deleita-se com a sua complexidade infinita e as suas inesgotáveis alegrias" (NovALIS 1989: 76) (Wer aber einen richtigen und geübten Natursinn hat, der genießt die Natur, indem er sie studirt, und freut sich ihrer unendlichen Mannichfaltigkeit, ihrer Unerschöpflichkeit im Genusse, NOVALIS 1977b: 105).

Tal atividade caprichosa retira a hierarquia entre homem e natureza, espírito e matéria, história humana e história natural, corpo e espírito e, especialmente, sujeito e objeto. Primeiro, observa-se uma equivalência radical entre o homem e os fenômenos 
LOSSO, E.G.B. - História, analogia e natureza em Novalis

quando eles se vinculam: “As relações com as forças da Natureza, os animais, as plantas, as pedras, as tempestades e as ondas devem necessariamente tornar os homens iguais a esses objectos". Segundo, a natureza possui um espírito que é discernido precisamente pela animação da percepção espiritual das coisas: "esta assimilação, esta transformação e esta resolução do humano e do divino em ingovernáveis forças, constituem o verdadeiro espírito da Natureza” (NovALIS 1989: 49). Terceiro, a história pessoal, humana e natural não podem ser separadas, porque existem entre elas nexos concretos e analógicos: "Todo o divino tem história; e a Natureza é o único todo com quem o homem pode compararse; desta forma, por que não haveria de estar, com ele, incluída numa história?” (NovALIS 1989: 65-66). Nesse momento, a "vara mágica da analogia" associa natureza e história. Como diz Hartmut Böhme: "a natureza não seria natureza, pois ela tem história, é uma força ativa e modeladora" (BöHME 2004: 146). Finalmente, o corpo passa a ser não um pedaço de matéria sem sentido, mas o principal canal de ligação de nosso espírito com o espírito da natureza: "As desconhecidas e misteriosas relações do nosso corpo pressupõem as desconhecidas e misteriosas relações da Natureza" (NovALIS 1989: 63).

Todas essas correlações vertiginosas entre natureza, espírito, corpo e história não podem ser feitas por um "homem de saber", isto é, um mero cientista. Somente podem ser encetadas pelo poeta, dono de mente e corpo perfeitamente antenados: "Só os poetas compreendem que significado a Natureza pode ter para o homem, comentou um formoso adolescente; não há risco em afirmar que reside neles a mais perfeita solução da humanidade" (NovAlis 1989: 66). A inferioridade objetiva dos poetas em relação aos especialistas é transfigurada, aqui, em superioridade espiritual. Como afirma Hartmut Böhme especialmente a respeito desse momento do livro, o formoso adolescente “identifica a afinidade oculta como o cerne da poesia” (BöHME 2004: 145).

No livro Natur und Subjekt, Böhme vai ainda mais longe num capítulo que analisa Heinrich de Ofterdingen. A associação já tradicional entre alquimia e mineração foi relacionada por Novalis à arte. O poeta fala de "um saber íntimo a respeito do interior da natureza". Isso demonstra que "o discurso romântico sobre a natureza está intrinsecamente ligado à prática pré-racional da alquimia e da cultura sagrada de mineração" (BÖHME 1988: 111). Em Os Discípulos de Sais, o nexo simbólico entre experiência terrestre e interiorização fica evidente quando uma voz fala que o mestre, mais velho, "Entrou em cavernas e soube de quantos estratos diferentes o edifício do Universo era formado. Moldou o barro para fazer rochas de estranhos feitios" (NovALIS 
LOSSO, E.G.B. - História, analogia e natureza em Novalis

1989: 33). Se a racionalidade faz o papel de recalque do maravilhamento operado por "combinações que uniam todas as coisas, as semelhanças, as coincidências" (NovALIS 1989: 33), tal retomada moderna das correspondências possui a função de produzir "cifras do recalcado e do inconsciente" "que se cristalizam como uma zona 'intraterrena' no interior do sujeito" (BÖHME 1988: 111). Em suma: “A raiz do anticapitalismo romântico e da crítica tecnológica está na filosofia natural [...] $\mathrm{O}$ autoconhecimento e o conhecimento natural fluem juntos [...] A poesia se torna o meio [Medium] do contexto natural [Naturzusammenhangs] e é o sucessor histórico da alquimia” (BÖHME 1988: 115). Como já vimos no trecho do "Monólogo", a linguagem, enquanto chave do reencantamento e da liberdade que abre a possibilidade de relação entre as coisas ao conter em sua autorreferencialidade um excesso de universalidade, é o instrumento poético inistrumentalizável da religação das coisas (NovALIS 1998: 195).

Como já foi dito acima, a primeira crítica romântica da racionalidade burguesa não teve como acontecer senão retomando o saber rechaçado, repelido e excluído das academias e do interesse público: a filosofia natural e sua semiologia da natureza. A indissociabilidade entre conhecimento natural e autoconhecimento desmonta a separação entre sujeito e objeto e permite a imersão na transfiguração do mundo, em um habitat miraculoso de combinações e coincidências.

\section{Astúcias da ilusão e do real}

Não se trata aqui de defender um retorno à episteme renascentista que acreditava em cifras divinas, muito menos de defender a retomada criativa dela por um sujeito romântico que a redescobre na infinitude de sua interioridade. Não se pode desconsiderar que tal sede de maravilhamento, tal deleite da analogia, é um narcótico poético, uma fantástica ilusão. Ao lado dessa natureza aurática, coroada de brilhos divinos, o poeta moderno se deparou com sua contraparte: a ironia (o polo oposto da analogia, segundo Octavio Paz) ou a perda da aura (segundo Benjamin).

Geralmente a crítica da poesia muito se confunde quando aborda a ambiguidade da ilusão no anseio poético: o que ilude é falso diante da realidade, mas tem seu momento de verdade como contraparte da mesma. E o momento de verdade de uma semiologia da natureza transmitida e transfigurada pela linguagem poética de Novalis é que a secura da relação entre o homem e as coisas imposta por uma mentalidade permanente de 
LOSSO, E.G.B. - História, analogia e natureza em Novalis

dominação da natureza também é falsa. Ela não enxerga outra coisa em objetos, materiais e mesmo animais, e até em trabalhadores humanos, senão formas de utilizá-los e explorálos. O que, então, é verdadeiro, a objetividade burguesa realista da dominação ou o amor pelo mistério das afinidades cifradas? Nem uma coisa nem outra: ambas são momentos de uma constelação de saberes à disposição da multiplicidade pós-moderna que, em conflito, devem ser repensados e confrontados.

Novalis, não em Os discípulos de Sais, mas em Cristandade e Europa, percebe que não há como o iluminismo banir o saber de semelhança, nem o romantismo recusar o iluminismo. O caminho que ele encontra é a grande síntese: a aliança final entre religião, ciência e poesia na figura do idealista erudito alemão. Essa utopia absurda, patentemente ingênua para olhos críticos atuais, não deixou de produzir uma lista imensa de epígonos bem mais iludidos e ingênuos: espiritismo, teosofia, antroposofia, o espiritualismo da contracultura, a Nova Era, a autoajuda, cujo exemplo culmina num best seller típico: $O$ ponto de mutação, de Fritjof Capra, publicado em 1982. Tais desejos de unificação entre ciência e espiritualidade prometem sempre um final feliz epistêmico festejante capaz de refletir a própria felicidade de tudo e de todos numa era de Aquário plenamente reconciliada.

Pensadores tão diferentes como Walter Benjamin, Octavio Paz, Hartmut Böhme e Michael Löwy não caíram nessa credulidade, pelo contrário, apontaram o engodo da aura, o abismo do niilismo. Ao mesmo tempo, não jogaram fora o bebê junto com água: perceberam que o desejo de tantos poetas modernos (depois de Novalis temos Baudelaire, Nerval, Rimbaud, Mallarmé, simbolistas, surrealistas, beatniks e muitos outros) pelo esplendor perceptivo da analogia esteve e está ligado a algo que sempre oscila entre o já perdido e o ainda rastreável. Quem lê a melodia verbal extática de Os discípulos de Sais não consegue negar que a literatura é capaz de transportar o usual desencanto para uma nova experiência de reencantamento, assim como uma audição de Bach, de Wagner (que tanto marcou os simbolistas), de Debussy, de Villa Lobos (em nosso modernismo), de Pink Floyd (na contracultura), do tropicalismo e do Clube da Esquina (em nossa peculiar contracultura brasileira).

O êxtase artístico, poético ou musical, e o sublime natural não vão encontrar a perfeita paz interior, não vão resolver problemas objetivos nem psicológicos, mas não são, tampouco, meras ninharias. A antropologia pós-moderna e especialmente sua vertente ecológica não tem convencido outras disciplinas a reconsiderar visões xamânicas

Pandaemonium, São Paulo, v. 23, n. 41, set.-dez. 2020, p. 125-152 
LOSSO, E.G.B. - História, analogia e natureza em Novalis

ameríndias como uma espécie de um outro modo de relação com o meio ambiente menosprezado porém essencial (INGOLD 2015: 61-62)? A ilusão não é tão ilusória assim, a realidade não é tão determinada assim; uma não é tão frágil quanto se pensa e a outra não é tão dominante. Na verdade, há uma verdadeira retroalimentação entre objetividade e imaginário e é essa implicação mútua entre as duas que esotéricos e teósofos, positivistas e neopositivistas não conseguiram levar em consideração. Tais doutrinas (neoplatonismo, hermetismo, mística, esoterismo, filosofia oculta) devem ser tratadas sempre com atenção a sua dupla face: ilusão e potencial utópico. Os poetas também estão metidos no meio dessa zona instável. Por isso a poesia se torna "o sucessor histórico da alquimia", logo, a alquimia permanece como rastro de anseios poéticos.

Em Cristandade ou Europa, o erudito alemão ficou encarregado do papel da resolução da guerra epistemológica entre Idade Média e Iluminismo. Já em Os discípulos de Sais, a tarefa do mestre é instruir os discípulos a resgatarem o saber perdido dos homens de outrora. Um livro está inserido nas primeiras propostas de filosofia da história, o outro é um romance que dramatiza as questões existenciais românticas num ambiente lendário. Se em Cristandade ou Europa o que predomina é uma perspectiva de síntese entre ciência, religião e poesia, em que o saber medieval cristão deve ser ressuscitado, em Os discípulos de Sais o ideal católico sai de cena para entrar um vago orientalismo lendário. Se a Idade Média católica estava, de certo modo, mascarando um anseio hermético não confessado no primeiro livro analisado, no segundo tal pendor analógico é incessante, constantemente exposto, mas também, ainda, mascarado de orientalismo lendário.

Vale ressaltar como o saber analógico é sempre desviado de seu assento histórico real, talvez porque ele, de fato, esteja disseminado em vários períodos históricos do passado (e certamente idealizado pelos seus defensores ingênuos como uma "tradição perene") e ligado a profundos arcaísmos animistas e mágicos. Aliás, o antropólogo Tim Ingold, por exemplo, defende não só que o animismo seja valorizado como uma verdadeira abertura para o mundo, mas também que seja reabilitado pela própria ciência: "Será que animismo e ciência são, portanto irreconciliáveis? Será que uma abertura animista para o mundo é inimiga da ciência? Certamente não", "nosso ato de repensar o animismo indígena levou-nos a propor a reanimação da nossa própria, assim chamada, tradição 'ocidental' de pensamento" (INGOLD 2015: 126). Talvez falte a antropólogos que 
LOSSO, E.G.B. - História, analogia e natureza em Novalis

têm defendido esse tipo de transformação radical da ciência conhecer melhor correntes do 'Ocidente' rejeitadas por eles mesmos.

E nesse caso, o ressurgimento glorioso de um princípio animista no Renascimento foi trabalhado como um projeto de magia erudita, para ser definitivamente derrotado pelo racionalismo científico. Quando Os discípulos de Sais o coloca num ambiente de culto egípcio, está sendo fiel a suas origens mais arcaicas, mas está camuflando o fato de que ele também foi, um dia, uma aspiração ocidental. Essa exposição ainda dissimulada em Os discípulos de Sais é sintoma, precisamente, do quanto que o saber da semelhança é o outro do Ocidente dentro dele mesmo, é o seu elemento mais recalcado, tratado como desprezível dentro do Ocidente porém curioso, exótico, interessante, conquanto esteja à distância, do lado de fora, no Oriente.

Mesmo quem é mais lúcido, entre psicanalistas, sociólogos, antropólogos, teóricos críticos e desconstrutivistas pode cair do erro de desconsiderar a importância da história do neoplatonismo, do hermetismo e da filosofia oculta para o anseio moderno por correspondências, o que os leva, inclusive, a avaliar muito mal esse campo de pesquisa essencial da poesia e desentender suas implicações e alcances. Novalis se esmerou em se fazer entender e demonstrar que há todo um treino, muito concreto, para o "sentido da Natureza" (Natursinn), o qual procurei destrinchar em toda a sua entusiasmada labuta com vistas à alteração da percepção. Tal trabalho é inevitavelmente comparável ao xamã ameríndio hoje em evidência, que também parte de um verdadeiro estudo minucioso dentro da experiência da alucinação ritual (só para dar um exemplo de Davi Kopenawa 2015: 458: "Nós somos habitantes da floresta. Nosso estudo é outro. Aprendemos as coisas bebendo o pó de yakoana com nossos xamãs mais antigos").

Se for para se introduzir numa problemática tão mal compreendida e cheia de armadilhas, tanto para o lado mais patente da ilusão dos teósofos quanto para o lado mais intrincado da ilusão dos supostamente desiludidos, do encantamento dos supostamente desencantados, suponho que Novalis seja um ótimo ponto de partida.

\section{Referências bibliográficas}

AGAMBEN, Giorgio. O reino e a glória: uma genealogia teológica da economia e do governo. Homo sacer, II, 2. São Paulo: Boitempo, 2011.

AgRIPPA, Henrique Cornélio. Três livros de filosofia oculta. Compilação e comentários Donald Tyson; tradução Marcos Malvezzi. São Paulo: Madras, 2008.

Pandaemonium, São Paulo, v. 23, n. 41, set.-dez. 2020, p. 125-152 
LOSSO, E.G.B. - História, analogia e natureza em Novalis

ANDRADE, Mario de. O empalhador de passarinho. São Paulo: Livraria Martins Editôra, 1953.

BERGENGRUEN, Maximilian. Magischer Organismus. Ritters und Novalis' 'Kunst, die Natur zu modificiren'. In: HeRMANN, Britta et al. (Org.). Ästhetische Erfindung der Moderne? Perspektiven und Modelle 1750-1850. Würzburg: Königshausen \& Neumann, 2003, p. 39-54.

BlumenBeRg, Hans. Die Lesbarkeit der Welt. Frankfurt am Main: Suhrkamp, 1989.

BÖHME, Hartmut. Natur und Subjekt. Frankfurt am Main: Suhrkamp, 1988.

BÖHME, Hartmut. O pétreo. Notas sobre a teoria do sublime a partir do olhar do "mais alheio ao homem". Pandaemonium Germanicum, n. 8, 2004, p. 121-150.

BöHME, Jakob. Werke. Die Morgenröte im Aufgang. De Signatura Rerum. Frankfurt am Main: Deutscher Klassiker, 2009.

CAndido, Antonio. A Educação Pela Noite \& Outros Ensaios. São Paulo: Ática, 1989.

CRUZ E SousA. Obra completa. Rio de Janeiro: Nova Aguilar, 1995.

Ficino, Marsilio; FARNDELL, Arthur; Blumsom, Peter. All things natural: Ficino on Plato's Timaeus. London: Shepheard-Walwyn Publishers, 2010.

FOUCAULT, Michel. As palavras e as coisas. Uma arqueologia das ciências humanas. São Paulo: Martins Fontes, 2000.

FRIEDRICH, Hugo. Estrutura da lírica moderna. São Paulo: Duas Cidades, 1978.

GoETHE, Johann Wolfgang von. Goethe's sämmtliche Werke. Stuttgart: J.G. Cotta, 1851.

Goodbody, Axel. Nature, Technology and Cultural Change in Twentieth-Century German Literature: the Challenge of Ecocriticism. New Perspectives in German Studies. Londres: Palgrave Macmillan, 2007.

HERDER, Johann Gottfried von. Ideen zur Philosophie der Geschichte der Menschheit, Bd. 2. Herausgegeben von Heinz Stolpe. Berlin und Weimar: Aufbau, 1965.

INGOLD, Tim. Estar vivo: ensaios sobre movimento, conhecimento e descrição. Petrópolis: Vozes, 2015.

JOLY, Bernard. L'alkahest, dissolvant universel ou quand la théorie rend pensable une pratique impossible. Revue d'histoire des sciences, n. 49-2-3, p. 305-344, 1996.

KoPenawa, Davi; Albert, Bruce. A queda do céu: Palavras de um xamã yanomami. São Paulo: Companhia das Letras, 2015.

KREMER, Detlef. Die romantische Theorie der Unverständlichkeit als ästhetisches Residuum der Esoterik. In: NeUgebAuer-WöLK, Monika (Org.). Aufklärung und Esoterik: Rezeption - Integration - Konfrontation. Tübingen: Niemeyer, 2008, p. 457-476.

KUSTER, Bernd. Transzendentale Einbildungskraft und asthetische Phantasie: zum Verhaltnis von philosophischem Idealismus und Romantik. Königstein: Forum Academicum in der Verlagsgruppe Athenaum, 1979.

LEUSING, Reinhard. Die Stimme als Erkenntnisform: zu Novalis' Roman “Die Lehrlinge zu Sais". Stuttgart: M. \& P., 1993.

LiMA, Luiz Costa. Lira e antilira. Rio de Janeiro: Civilização Brasileira, 1968.

Michaud, Guy. Méssage poétique du symbolisme. Paris: Nizet, 1961.

Michelet, Émile. De l'ésotérisme dans l'art. Paris: G. Carré, 1890.

NovALIS. Schriften. Die Werke Friedrich von Hardenbergs. Organização Paul Kluckhohn und Richard Samuel. Stuttgart: Kohlhammer, 1977a. t. 3.

Novalis. Schriften. Die Werke Friedrich von Hardenbergs. Organização Paul Kluckhohn und Richard Samuel. Stuttgart: Kohlhammer, 1977b. t. 1.

Novalis. Pólen: fragmentos, diálogos, monólogo. Organização Rubens Rodrigues Torres, Filho. São Paulo: Iluminuras, 1988.

NovALIS. Os discípulos de Saïs. Tradução Luís Bruhein. Lisboa: Hiena Editora, 1989.

Pandaemonium, São Paulo, v. 23, n. 41, set.-dez. 2020, p. 125-152 
LOSSO, E.G.B. - História, analogia e natureza em Novalis

NovALIS. A Cristandade ou A Europa: um fragmento (escrito no ano de 1799). Tradução José M. Justo. Lisboa: Hiena, 1991.

Novalis. Himnos a la noche. Enrique de Ofterdingen. Tradução Eustaquio Barjau. Madrid: Cátedra, 1998.

ORIGÈnE. Homélies sur le cantique des cantiques. Introdução, tradução e notas Dom O. Rousseau. Paris: Du Cerf, 1953.

PARACELSO. A chave da Alquimia. Rio de Janeiro: Editora Três, 1973.

PARACELSUS. Vom Licht der Natur. Stuttgart: Reclam, 1970.

PAZ, Octavio. Filhos do barro: do romantismo à vanguarda. Rio de Janeiro: Nova Fronteira, 1984.

Platão. Timeu-Crítias. Trad. de Rodolfo Lopes. Coimbra: Centro de Estudos Clássicos e Humanísticos, 2011.

RIGBY, Kate. "Mines aren't really like that": German Romantic Undergrounds Revisited. In: SCHAUMANN, Caroline; Suldivan, Heather I. German Ecocriticism in the Anthropocene. New York: Palgrave Macmillan, 2017, p. 111-128.

Romano, Roberto. Conservadorismo romântico: origem do totalitarismo. São Paulo: Fundação Editora UNESP, 1997.

SCHIERBAUM, Martin. Friedrich von Hardenbergs poetisierte Rhetorik. Politische Ästhetik der Frühromantik. Paderborn: Ferdinand Schoningh, 2002.

Seligmann-Silva, Marcio. Ler o livro do mundo. Walter Benjamin: Romantismo e crítica literária. São Paulo: Iluminuras, 1999.

VIDAL-NAQUET, Pierre. The Atlantis story: a short history of Plato's myth. Exeter: University of Exeter Press, 2007.

WINCKELMANN, Johann Joachim; EISELEIN, Joseph. Johann Winckelmanns sämtliche Werke. Einzige vollständige Ausgabe. 6.Bd. Geschichte der Kunst des Altertums. 1767-1768. Donauöschingen: Deutscher Classiker, 1825.

YATES, Frances. Giordano Bruno e a tradição hermética. São Paulo: Cultrix, 1995.

ZANUCCHI, Mario. Novalis - Poesie und Geschichtlichkeit: die Poetik Friedrich von Hardenbergs. Paderborn: Schöningh, 2006. 